УдК 340.15:343.26
Сокальська О. В., кандидат юридичних наук, доцент, старший науковий співробітник науково- дослідного центру з питань діяльності органів та установ Державної кримінально-виконавчої служби України і пробації Інституту кримінально- виконавчої служби

\title{
ВИТОКИ АНГЛІЙСЬКОЇ ТЮРЕМНОЇ РЕФОРМИ (XVI-XVIII СТОЛІТТЯ)
}

У статті досліджено тюремну систему Англії XVI-XVIII ст., проаналізовано пам'ятки пенітенціарної думки Англії XVI-XVIII ст., висвітлено погляди та ідеї правників, громадських і релігійних діячів на стан тюрем та шляхи реформування тюремної системи, що стали підгрунтям формування англійської пенітенціарної моделі наприкінці XVIII ст.

Ключові слова: Англія; тюремна система; тюремна реформа; пенітенціарні ідеї; Томас Брей; Джонас Хенуей.

В статье исследуется тюремная система Англии XVI-XVIII вв. Автором проанализированы памятки пенитенциарной мысли Англии XVI-XVIII вв., отображены взгляды юристов, общественных и религиозных деятелей на состояние тюрем и пути реформирования тюремной системы, ставшие основой английской пенитенциарной модели, сформировавшейся в конце XVIII в.

Ключевые слова: Англия; тюремная система; тюремная реформа; пенитенциарные идеи; Томас Брей; Джонас Хенуей.

Постановка проблеми. Пенітенціарні системи як концепт виправного покарання, ключовим елементом якого $\epsilon$ ізоляція й утримання особи в умовах, які б сприяли покаянню і моральному переродженню, сформувалися в США на початку XIX ст. Однак, як зазначав один із піонерів пенітенціарної науки, професор Харківського університету О. Полюмбецький, «думка про перетворення тюрем в Англії виникла у той же час, що і в Америці, можна навіть сказати, що раніше» $[1$, с. 46]. Аналіз передумов виникнення американських тюремних систем свід- чить, що і квакери Філадельфії, і тюремні реформатори Нью-Йорка базувалися на цілком розробленій у Старому світі пенітенціарній доктрині, яка була лише реалізована ними в конкретних історичних та економічних умовах. За основу ж було взято ідеї англійських тюремних реформаторів і гуманістичні принципи французьких просвітителів.

На момент війни за незалежність американських колоній у метрополії уже понад 100 років активно обговорювалися питання реформування тюрем, було розроблено теоретичні концепти, ухвалено низку 
законодавчих актів та намічено напрями реалізації тюремних перетворень. Тому, на нашу думку, вивчення історії пенітенціарних систем неможливе без розуміння еволюції англійської тюремної системи та пенітенціарної думки, аналізу ідей та поглядів англійських релігійних, державних діячів, філантропів та правників.

Постановка завдання. В історико-правовій літературі та пенологічних дослідженнях англійську тюремну реформу частіше всього пов'язують з іменем Джона Говарда (John Howard) як родоначальника реформаторського руху за покращення тюрем. Однак в англійському громадському та науковому дискурсі упродовж XVII-XVIII ст., задовго до Дж. Говарда, було сформовано теоретичне підгрунтя тюремних перетворень і окреслено практичні шляхи їх реалізації. Мета статті - дослідити та проаналізувати пам'ятки пенітенціарної думки Англії, зокрема раніше невідомі вітчизняній історіографії: «Есе про реформування тюрми Ньюгейт та інших в'язниць Лондона й околиць» («Essay Towards the Reformation of Newgate and Other Prisons in and about London») 1702 р. Томаса Брея [2] та «Одиночне ув'язнення: 3 належною прибутковою працею i відповідним утриманням як найбільш гуманний і дієвий засіб покарання злочинців...» («Solitude in Imprisonment: With Proper Profitable Labour and a Spare Diet, the Most Humane and Effectual Means of Bringing Malefactors...») 1776 p. Джонаса Хенуея [3], що $\epsilon$ цінним джерелом для вивчення витоків тюремної реформи; уточнити хронологію формування пенітенціарних ідей; висвітлити погляди правників, громадських і релігійних діячів на стан тюрем та шляхи реформування каральної системи Англії в конкретних історичних умовах.

Аналіз останніх досліджень і публікацій. Ще М. Таганцев писав, що література 3 тюремного питання в Англії є неосяжною [4]. 3 того часу досліджень 3 історії англійської в'язничної системи лише побільшало. Однак в українській історикоправовій літературі ця тема майже не висвітлювалася. Тож звернімося до зарубіжної історіографії. Насамперед, слід акцентувати увагу на першоджерелах, а саме роботах англійських філософів, філантропів, релігійних діячів і правників, зокрема T. Mopa (T. More), Дж. Фокса (G. Fox), Т. Брея (T. Bray), В. Ідена (W. Eden) та Дж. Хенуея (J. Hanway) [5; 6; 2; 7; 8]. Також нами використано класичні праці 3 окресленої проблематики М. Ігнатьєва (M. Ignatieff), Р. МакГовена (R. McGowen), Ш. Мак-Конвіла (S. McConville), Д. Мелосci (D. Melossi) та М. Паваріні (M. Pavarini), Б. Уебб (B. Webb) i C. Уебб (S. Webb) [9; 10; 11; 12; 13]. Одними з перших авторів, які досліджували ранню історію англійської тюремної системи в Російській імперії, були О.Полюмбецький i Г. Сліозберг [1; 14]. 3-поміж сучасної історіографії на особливу увагу заслуговують грунтовні дослідження Р. Андреященка, С. Васильєвої, О. Марукова й П. Тепляшина [15; 16; 17; 18; 19].

Виклад основного матеріалу. Ідеї щодо реформування тюрем в Англії зародилися в той період, коли в інших країнах в'язниця лише формувалася як каральна інституція. Це можна пояснити тим, що англійська тюремна система сформувалася доволі рано. У другій половині XII ст. відповідно до Кларендонської ассизи 
було започатковано державні тюрми графств, що перебували у віданні шерифів. Крім того, існувала мережа місць ув'язнення, підконтрольних місцевим феодалам та церкві [15, c. 14]. Міста також були зобов'язані утримувати в'язниці для боржників і підслідних.

Упродовж наступних століть стрімко збільшувалася кількість правопорушень, які каралися тюремним ув'язненням. На початку XVI ст. їх було вже понад 180, серед них - бродяжництво, лжесвідчення, порушення громадського порядку або моралі, наклеп тощо $[17$, с. 20-21]. Ще у XIII cт. постала проблема переповнення державних тюрем. Спеціально створені комісії проводили інспекції тюрем графств $з$ метою прискорення правосуддя - звільняли засуджених для того, щоб вивільнити місця для інших $[17$, с. 23$]$.

Однією з перших робіт, що порушувала питання ефективності покарання й устрою тюрем, була «Утопія» Томаса Мора (1516 р.). 500 років тому відомий філософ наполягав на застосуванні до засуджених заходів виховного впливу, відводячи позбавленню волі з примусовими роботами ключову роль у системі покарань. Злодіїв же слід було карати громадськими роботами без позбавлення волі. Пенітенціарна практика Утопії не була спрямована на заподіяння злочинцю зайвих і непотрібних страждань, праця засуджених мала використовуватися ефективно, а тих, хто старанно працював, замикали б у камерах лише на ніч [5]. Ідеї Т. Мора, як слушно зазначав М.Гернет, «були провісниками того, що з'явилося лише через сотні років, або залишаються провісниками й нині невідомого майбутнього» [20, с. 473]. I справді, лише через 300 років було впроваджено оборонську систему, коли злочинців замикали в одиночних камерах на ніч, а вдень вони працювали під суворим наглядом. Нині ж вільне перебування засуджених у закритому периметрі установ виконання покарань - звична практика в західноєвропейських в'язницях, лише після відбою їх замикають у камерах.

Погляди на систему покарання i режим утримання злочинців в «Утопії» значно випереджали свій час і були протиставлені існуючим в Англії на початку XVI ст. засобам боротьби зі злочинністю.

Індустріальний розвиток Англії зумовив створення в середині XVI ст. нових місць несвободи - виправних будинків для утримання і використання праці волоцюг, міської бідноти, дрібних правопорушників. 1553 року для потреб нужденних передано королівський палац Брайдуел (Bridewell Palace), у подальшому так стали називати й інші подібні заклади. Указ 1576 р. приписував відкрити виправні будинки в кожному графстві [19]. Підпорядковувалися вони не шери-

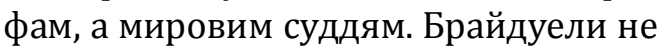
лише повинні були виконувати функцію своєрідного соціального контролю, а й приносити прибуток, за рахунок якого утримувався б заклад. Однак, на практиці, в економічному сенсі брайдуели не витримували конкуренції з мануфактурами, а в соціальному - були не школами виправлення та смиренної праці, а «клоаками» гріха та злочинності. 1609 року на законодавчому рівні приписано утримувати в брайдуелах винятково осіб, що відбували покарання, 3 обов'язковим залученням їх до важкої праці. Саме через це злочинці всіляко намагалися уникнути перебування у 
виправних будинках, воліючи відбувати покарання у звичайних тюрмах [19].

Окремою проблемою були боргові тюрми. 1618 року Джеффрі Міншулл (Geoffrey Mynshull) опублікував книгу «Essays and Character of a Prison and Prisoners», у якій з власного досвіду описав реалії боргової тюрми, назвавши їі школою підлості, будинком аморальності й осередком розпусти [14, с. 111]. Лише 1670 р. ухвалено парламентський акт, який приписував утримувати боржників окремо від злочинців.

Переповненість тюрем спонукала владу шукати як альтернативні види покарання (1596 р. розширено застосування кримінального заслання (транспортації)), так і додаткові кошти на утримання в'язнів. За відсутності державного фінансування шериф самостійно повинен був опікуватися бюджетом тюрми. Це призводило до того, що тюрми фактично перетворювалися на приватні, де панувало беззаконня та свавілля тюремників. Праця в'язнів за таких обставин розглядалася не як засіб виправлення, а як спосіб самоокупності в'язниць.

Наприкінці XVII ст. у роботі англійського економіста, квакера Джона Беллерса (John Bellers) трудова зайнятість названа ключовим елементом у процесі виправлення злочинця. Саме Дж.Беллерс одним із перших озвучив ідею виправного покарання. Мислитель, виступаючи проти смертної кари, підкреслював економічну недоцільність для держави вбивства злочинців. Натомість слід використовувати їхню працю, але не для покарання, а для відшкодування спричинених злочином збитків. У своєму есе 1699 р. Дж. Беллерс порівнював сус- пільство із сім'єю, член якої оступився, учинивши злочин; за таких обставин сім'я зробила б усе, щоб зберегти йому життя і направити на правильний шлях. Так і суспільство, створивши в тюрмах гідні умови утримання, підтримувало би свого «блудного сина», даючи йому можливість змінитися на краще $[16$, с.67]. Теза Дж. Беллерса, що «суспільство робить достатньо для свого захисту, коли знешкоджує вбивцю, помістивши його в тюрму, а щось більше - вже помста» [21] не втратила своєї актуальності.

Дж. Беллерс також був автором концепції промислового коледжу для бідноти [22]. Наприкінці XVII - на початку XVIII ст. проблема боротьби 3 пауперизмом в Англії постала досить гостро. Було організовано робітні будинки, що являли собою щось середнє між нічліжкою, фабрикою, виправною тюрмою і богадільнею. Умови утримання в робітних будинках були досить схожими з виправними будинками. Закон про робітні будинки 1723 р. приписував створити подібні заклади в усіх графствах. Досвід англійських робітних будинків пізніше буде використано при розробленні концепції виправного покарання англійськими просвітителями XVIII ст.

На початку XVIII ст. основними місцями позбавлення волі для правопорушників в Англії залишалися тюрми графств (Goals) та виправні тюрми (Bridewell), що перебували у віданні місцевої влади - шерифів і мирових суддів відповідно. 1699 року парламент ухвалив Goal Act, яким на суддів покладалася відповідальність за побудову, ремонт та утримання тюрем графств. Саме в них, а не в приватних установах, слід 
було утримувати засуджених за тяжкі злочини [10, с. 112].

Центральна влада майже не опікувалася проблемою тюрем. Першими, хто закликав політиків і громадськість звернути увагу на їх жахливий стан, були релігійні товариства методистів та квакерів. Методисти, поряд 3 іншими соціальними проектами, організовували регулярні відвідини в'язниць, опікувалися санітарним станом тощо. Результатом їх палких проповідей у тюремних камерах стало навернення не лише сотень прихильників серед засуджених, а й тюремників [23, с. 93]. Визнані владою поза законом англійські дисиденти на собі нерідко відчували всі злидні тюремного ув'язнення. Каральна політика держави, часті смертні вироки, тюремне ув'язнення за віровідступництво гостро критикувалися ідеологами квакеризму. «Тюремні наглядачі не повинні бути п'яницями, лихословами та гнобителями людей, - писав у середині XVII ст. засновник Релігійного товариства друзів Джордж Фокс, - а навпаки, хорошим прикладом для засуджених. Не слід утримувати нікого в тюрмі надто довго, оскільки тюрма лише псує людину - перебуваючи серед злочинців, засуджений вчиться злу [...] В'язниці мають бути влаштовані у відповідних місцях з гідними умовами утримання». Також він вимагав скасування тюремних зборів, без сплати яких засуджений не міг вийти на свободу навіть після закінчення строку ув'язнення [6].

Систематичні інспекції тюрем проводили також представники англіканської церкви. Члени Товариства поширення християнських знань упродовж 1699-1702 рр. відвідали місця ув'язнення Лондона і виявили численні недоліки та зловживання в тюрмах «Ньюгейт» і «Маршалсі». Крім звіту про стан тюрем, головою товариства Томасом Бреєм підготовлено пропозиції щодо реформування тюремної системи та режиму утримання - «Essay Towards the Reformation of Newgate and Other Prisons in and about London» (1702р.). Англійський публіцист Вільям Діксон назвав цей документ однією з перших пам'яток пенологічної думки Англії [2, p. 33].

В есе перелічено всі вади тогочасних англійських в'язниць: персонал - аморальний і не відповідає жодним вимогам, а лише розбещує засуджених, особливо жінок; тюремники нерідко перебувають у змові зі злочинцями, за гроші дозволяють приводити в камери жінок; засуджені постійно вживають алкоголь, який їм продають наглядачі, богохульствують і лихословлять, грають в азартні ігри; через спільне утримання запеклі злочинці «псують» новачків; у в'язницях не дотримуються церковних обрядів тощо. Відповідно до визначених проблем, задля покращення тюремного режиму пропонувалося:

- щодо управління в'язницею $і$ тюремних службовців: 1) установити жорстку дисципліну для тюремників; 2) при відборі кандидатів на посади наглядачів оцінювати їх моральні якості; 3) ті, хто купив посади, але ведуть себе непристойно, мають бути звільнені; 4) заборонити будь-які преференції засудженим з боку адміністрації та їх неформальні контакти; 5) запобігати і не допускати підкуп службовців засудженими; 6) тюремники мають утримуватися від будь-якої грошової винагороди, 
крім заробітної плати, також вони забезпечуються житлом та їжею; 7) у кожній в'язниці мають бути «ордери» (Table of Orders) з чітким переліком обов'язків тюремників і засуджених, а також видів дисциплінарних покарань та заохочень, їх слід зачитувати один раз у місяць засудженим і наглядачам;

- щодо засуджених: 1) за можливості, утримувати злочинців слід в одиночних камерах, як це практикується в лікарнях; 2) запеклих злочинців необхідно утримувати окремо від тих, хто вчинив злочин уперше; 3) жінки повинні відбувати покарання в осібному приміщені, а наглядачів, які б дозволяли контакти засуджених чоловіків з жінками, крім їхніх дружин, слід суворо карти; 4) засуджені повинні тяжко працювати багато годин на день; 5) слід заборонити вживання алкогольних напоїв i продаж їх тюремниками, а також «тюремні традиції», пов'язані з уживанням алкоголю, як то пригощання співкамерників новоприбулими злочинцями; 6) заборонити i суворо карати за азартні ігри, богохульство, лихослів'я; 7) на кожного засудженого мають бути заведені облікові картки, де б фіксувалися всі проступки, порушення дисципліни, а також позитивні зміни в їх поведінці; ці картки обов'язково мають пред'являтися в суді, а також при звільненні; негативна поведінка в тюрмі має враховуватися суддею як обставина, що обтяжує покарання; 8) особу, після звільнення з в'язниці, бажано було би певним чином підтримувати: запеклих злочинців слід направляти в робітні будинки, де б за ними здійснювався нагляд, їх звільнення можливе було лише за умови сумлінної праці, а тим, хто добре поводився під час ув'язнення, - підшуковувати роботу, щоб вони не повернулися до злочинної діяльності;

- щодо релігійного впливу: 1) увести оплачувані посади священників, які б регулярно (один раз на тиждень) відвідували в'язниці та складали звіти про їх стан; до таких священнослужителів висувати високі вимоги щодо їх побожності та порядності; 2) у тюрмах мають проходити богослужіння, кожного дня обов'язково зранку і ввечері читати молитви; 3) священики повинні вести бесіди із засудженими, навчати їх, спонукати до законослухняної поведінки в майбутньому; 4) засуджені мають забезпечуватися релігійною літературою [2, p. 33-40].

Наприкінці свого есе Т. Брей висловив сподівання, що Лорд-мер і шериф Лондона візьмуть справу тюремної реформи під свій контроль. Автор акцентував увагу на тому, що тюремні перетворення можуть стати вагомою складовою загальносоціальних змін, оскільки саме тюрми мають виправляти злочинців; і якщо тюрма виконає своє завдання, то людина вже не буде становити небезпеки для суспільства. На практиці ж, зазначав Т. Брей, виходить так, що після в'язниці засуджений стає ще гіршим, а якщо туди потрапляє невинуватий, то він піддається розпусті й порокам, перетворюючись на професійного злочинця [2, p. 41].

Доповідь Т. Брея залишилася не поміченою владою, як і виявлені в ході перевірки 1696 р. численні зловживання в тюрмі Фліт. Однак його ідеї мали неабиякий вплив на члена парламенту, генерала Джеймса Оглторпа (James Oglethorpe), який особисто був знайомий з Т. Бреєм [11, p. 55]. 3 ініціативи Дж. Оглторпа 1729 . 
створено парламентський комітет 3 вивчення стану тюрем. Поштовхом до цього стала особиста трагедія - близький друг Дж. Оголторпа Роберт Кастел потрапив до боргової тюрми. Оскільки йому нічим було заплатити тюремникам за гідні умови утримання, то його помістили в камеру разом із хворим на віспу, у результаті чого Р.ККастел захворів і незабаром помep.

Члени комітету, очолюваного Дж. Оглторпоп, декілька місяців провели, інспектуючи в'язниці. Результати їх розслідування були невтішні й набули неабиякого розголосу не лише в метрополії, оскільки виявили жахливі умови утримання засуджених, підслідних і боржників, численні зловживання тюремної адміністрації, велику кількість ув'язнених за борги. Після оприлюднення звіту комітету багато очільників тюрем було притягнуто до відповідальності, а жорстоке поводження з ув'язненими заборонено.

Джеймсу Оглторпу також удалося провести через парламент закон про боргові тюрми, згідно з яким боржники, які би погодилися переселитися до Північної Америки й заснувати там колонію, звільнялися би з боргової тюрми. 1732 року для реалізації цього соціального проекту Дж. Оглторп отримав дозвіл на заснування колонії, названої Джорджія [24].

1730 року Вільям Хей подав до парламенту законопроект про будівництво нових місцевих тюрем, діяльність яких контролювалася б інспекторами, призначеними Лордканцлером [11, p. 55]. Це було одним із перших кроків на шляху встановлення централізованого державного контролю за діяльністю в'язниць.
Розгляд питання про стан тюрем на рівні парламентського комітету дав поштовх до гострої критики англійського кримінального права, системи покарань (смертна кара призначалася більше ніж за 200 злочинів: від убивств до дрібних крадіжок та проступків) та устрою тюрем. За редакцією знаного юриста Соллома Емліна (Sollom Emlyn) 1730 р. опубліковано шеститомну збірку «A complete collection of state-trials, and proceedings for high-treason, and other crimes and misdemeanors: from the reign of King Richard II to the end of the reign of King George I», у якій автор досить негативно оцінював тогочасне англійське судочинство, що вимагало реформування, і звертав особливу увагу на незадовільне управління тюрмами [25]. 1750 року створено парламентський комітет з перегляду кримінального законодавства, тоді ж уперше порушено питання про гуманізацію покарання [26, р. 28].

1750 року вибухнув новий скандал у столичній тюрмі King's Bench Prison. Розслідування зловживань, фактів жорсткого поводження із засудженими та переповнення в'язниці призвели до ухвалення 1754 р. парламентського акта (King's Bench Prison Act), що приписував звести нову будівлю тюрми, оскільки діюча була непридатна для утримання засуджених. На це парламентом виділено $7800 £$ та придбано $2 \frac{1}{2} 2$ акра землі. У новій тюрмі були справді розкішні умови для боржників: два магазини, великі кімнати, можливість короткочасних «відпусток», але лише для тих, хто міг за це заплатити [27].

У переважній більшості в'язниць начальники й тюремники активно торгували не лише продуктами харчування та алкогольними на- 
поями, а й певними привілеями. Для того, щоб залишити тюрму після завершення строку ув'язнення, слід було заплатити; якщо в засудженого таких коштів не було, то він лишався у в'язниці на невизначений період. Так, у тюрмі Фліт членами парламентського комітету виявлено п'ятдесят дві особи, залишені там незаконно упродовж дев'яти, десяти й одинадцяти років.

Англійські в'язниці у XVIII ст. перебували у вкрай жалюгідному стані та були віддані на відкуп тюремникам (офіційної зарплатні у наглядачів і начальників в'язниць не було - O.C.). Ось як описував англійські тюрми відомий філантроп Дж. Говард: жодного розділення засуджених за категоріями; нерідко разом з боржниками перебували їхні сім'ї; у переповнених камерах - задуха і сморід, в'язні в лахмітті, напівголі й голодні; рідко коли в тюрмі були відхожі місця. У таких антисанітарних умовах засуджені постійно хворіли. Неодноразово підсудні заражали «тюремною лихоманкою» членів суду та всіх присутніх на судовому засіданні, інколи її жертвами ставали цілі міста [4].

Призначення Дж. Говарда 1773 р. шерифом Бедфордширу було зумовлене активною діяльністю місцевої політичної еліти з лобіювання «тюремних» законів, що регламентували питання утримання у в'язницях представників духовенства та боржників. Серед прихильників законопроекту були депутати від Бедфордширу в Палаті громад Роберт Хенлі Онглі (Robert Henley Ongley) та Ceмюел Вітбред (Samuel Whitbread). 3 останнім Дж. Говарда пов'язували дружні стосунки ще з дитинства. Так Дж. Говард, який відповідно до зако- ну не міг обіймати таку високу посаду в місцевій адміністрації, оскільки не відповідав професійним вимогам і не належав до англіканської церкви, став шерифом і розпочав активну діяльність 3 інспектування тюрем задля реалізації тюремних перетворень [28].

Слід зазначити, що після видання 1770 р. англійського перекладу праці Чезаре Беккаріа «Про злочини і покарання» серед політичної еліти активізувався інтерес до проблеми кримінальних покарань i, зокрема, позбавлення волі в умовах оновленої тюрми, яка б виправляла злочинців. Того ж року створено черговий парламентський комітет з тюремних питань.

1771 року Вільям Іден опублікував працю «Принципи кримінального права», у якій наполягав на широкому застосуванні строкового тюремного ув'язнення як покарання за більшість злочинів і кримінальних проступків. Він звертав увагу на необхідність опіки держави над засудженим, гуманне ставлення до нього задля збереження людини для суспільства [7].

1775 року побачила світ книга Дж. Хенуея «The Defects of Police». Автор був противником спільних робіт ув'язнених і наполягав на одиночному утриманні, що давало б засудженому можливість більше заглибитися у свій внутрішній світ, переоцінити свої моральні установки тощо. Ідеальну, на думку Дж. Хенуея, тюрму, де душа людини змінювалася б, він назвав реформаторієм. Засуджені мали забезпечуватися достатньою кількістю їжі, утримуватися в комфортних, безпечних для здоров'я умовах, не повинно бути насильства ні словом, ні ділом. Особлива роль 
відводилася священику, який би щодня відвідував засуджених і стежив за їх виправленням. Сам дух тюрми, уважав Дж. Хенуей, повинен нести покаяння; тоді найзапекліший злочинець буде змінюватися. У своїй праці автор детально описав, якою повинна бути будівля, устрій виправного закладу, розмір камер тощо. Фактично, це був перший проект тюрми нового зразка [8].

Принцип одиночного утримання засуджених із залученням до праці та відповідними умовами утримання Дж. Хенуей називав найбільш гуманним та дієвим засобом покарання злочинців та перетворення їх на законослухняних громадян. Його роботу з відповідною назвою - «Solitude in Imprisonment: With Proper Profitable Labour and a Spare Diet, the Most Humane and Effectual Means of Bringing Malefactors...» опубліковано 1776 р. Саме в ній більш детально окреслено погляди автора на устрій та функціонування місць ув'язнення.

Дж. Хенуей сформулював правила гуманного управління брайдуелами, у яких відбували покарання переважно повії: жінок-засуджених слід було утримувати в окремих одиночних камерах, достатньо освітлених та провітрюваних, з ними слід було проводити виховні бесіди, ознайомлювати 3 релігійною літературою, вчити молитов, тих, хто не вміє читати - навчати, привчати до гігієни; їжа та одяг засуджених мали бути достойними. Матрона та жінкинаглядачки мають бути благочестивими та релігійними, призначати їх слід за погодженням з представниками місцевої влади [3, p. 29-32]. Дж. Хенуей був переконаний: якщо звичкою засудженого стане заняття корисними справами, то після пере- бування у в'язниці чи виправному домі він зможе чесно заробляти на життя.

У зазначеній роботі Дж. Хенуей фактично заклав основи концепції одиночного утримання 3 урахуванням специфіки людини як істоти, що замислюється над свою поведінкою, здатна до внутрішніх рефлексій i розкаяння через усвідомлення своєї вини, що повинно посилюватися в умовах самотності. Наполягаючи на виключності суворого одиночного утримання і палко відстоюючи його, Дж. Хенуей усе ж полемізував і наводив закиди противників такого режиму: «Єдині заперечення, які я чув щодо свого плану, це: по-перше, що Ви хочете зробити в'язницю у в'язниці. На що я відповідаю, що і за існуючого режиму засуджені замкнені у своїх камерах. Чи це не в'язниця у в'язниці? До них не допущені жодні відвідувачі. По-друге, запропоноване покарання занадто м'яке. На це я відповідаю. Ви вважаєте, що самотність не достатньо страшна або що вона не дасть ніякого доброго ефекту? Третє застереження порушує більш серйозну проблему: одиночне ув'язнення занадто суворе, жах самотності спонукатиме засудженого до самогубства» [3, p. 103-104]. Як бачимо, ще 1776 р., при формуванні концепції одиночного утримання постало питання про ментальне здоров'я засуджених в умовах усамітнення і про можливі самогубства - тобто те, що змусить через 100 років відмовитися від системи суворого одиночного утримання в європейських тюрмах. Думаємо, послідовники Дж. Хенуея - пенсильванські тюремні реформатори, палкі прихильники суворого одиночного утримання - просто проігнорували 
це застереження. Сам Дж. Хенуей, відповідаючи на нього, зазначав, що не зустрічав випадків самогубств у тюрмі, крім злочинців, засуджених до публічної ганебної смертної кари. На його думку, в умовах одиночного ув'язнення особа навпаки повертається до чеснот, а чесноти - це шлях до щастя, а не самогубства. Особисто автор, якщо потрібно було б обирати, волів би відбувати тюремне ув'язнення в одиночній камері, де було б письмове приладдя та книги, аніж у товаристві небезпечних злочинців. Хоча і він визнавав, що людина не створена для того, щоб залишатися на самоті [3, p. 105].

Ідеї Дж. Хенуея про організацію тюремного режиму, обов'язкове залучення засуджених до праці та одиночне утримання надалі лягли в основу англійської пенітенціарної моделі та філадельфійської пенітенціарної системи. Саме вони були використані тюремними реформаторами, у тому числі Дж. Говардом, наприкінці XVIII - на початку XIX ст., на першому етапі реалізації тюремної реформи в Англії.

Висновки. Отже, можемо констатувати, що тюремна система Англії, яка включала мережу місцевих тюрем графств, підпорядкованих шерифам, тюрми феодалів та міські в'язниці, почала формуватися у другій половині XII ст. Тюремне ув'язнення як вид покарання утвердилося в системі каральних заходів англійського права, починаючи 3 XVI cт. I відразу ж постало питання умов та режиму утримання засуджених і боржників.

Ідеї виховного впливу, а не лише ізоляції, під час тюремного ув'язнення, поєднаного з обов'язковим залученням до праці 3 метою утилітарного використання засуджених без спричинення їм зайвих страждань уперше викладено 1516 р. в «Утопії» Т. Мора. Заклики до реформування в'язниць та покращення умов утримання постійно лунали в роботах англійських дисидентів, 3окрема представників релігійного Товариства друзів. Засновник квакеризму Дж. Фокс у середині XVII ст. сформулював вимоги до тюремного персоналу («тюремні наглядачі не повинні бути п'яницями, лихословами та гнобителями людей, а хорошим прикладом для засуджених») i наполягав на шкідливості тривалого тюремного ув'язнення («не слід утримувати нікого в тюрмі надто довго, оскільки тюрма лише псує людину - перебуваючи серед злочинців, засуджений вчиться злу»). 1659 року Дж. Фокс озвучив вимогу про гідні умови утримання засуджених у відповідних спеціалізованих закладах.

Залучення засуджених до праці, навчання ремеслам задля подальшого працевлаштування повинно було стати основою виправного покарання, вперше обгрунтованого Дж. Беллерсом 1699 р. Опіка квакерами осіб, що вчинили злочин, у Дж. Беллерса переростає в загальну тезу, що суспільство, подібно сім'ї, несе відповідальність за свого члена, який оступився, і має дбати про нього, давати шанс змінитися на краще.

До початку XVIII ст. зазначені ідеї були лише складовою реформаторських тез філософів і релігійних діячів. Першою власне програмою пенітенціарних перетворень з упевненістю можемо назвати есе Т.Брея про реформування тюрем 1702 р., у якому системно викладено всі вади тогочасних англійських в'язниць i 
запропоновано шляхи реформування за напрямами: управління в'язницею і тюремний персонал, режим та умови відбування покарання, духовна опіка та діяльність в'язничного священика. Т. Брей першим запропонував одиночне утримання як найбільш ефективний спосіб реалізації покарання у виді позбавлення волі, а також ведення письмового обліку стягнень і заохочень засуджених, що в подальшому враховувалося б судом; озвучив ідею постпенітенціарної опіки.

Як бачимо, принципи, що стали основою пенітенціарної моделі реалізації покарання у виді тюремного ув'язнення XIX ст., були вперше сформульовані 1702 р. Але в Англії вони лишалися незатребуваними понад 150 років. I лише у другій половині XVIII ст., 3 початком трансформації системи покарань, основним видом яких мало стати тюремне ув'язнення
3 метою виправлення злочинця, погляди державних і громадських діячів звернуто на тюремні реформи, оскільки «стара» в'язниця для реалізації цієї мети підходила мало.

Ідеї попередників узагальнено та доповнено Дж. Хенуеєм. У його роботах 1775-1776 рр. викладено основні погляди на засади організації виправної тюрми-реформаторію, а саме одиночне ув'язнення в гідних умовах, релігійна опіка та спокута, примусове залучення засуджених до праці.

Утілення в життя ідей щодо реформування тюрем, започаткованих мислителями та релігійними діячами, лягло на плечі філантропів та членів парламентських комісій у 80-х роках XVIII ст. I хоча найбільш відомим 3 них залишається Дж. Говард, його діяльність була лише частиною в системному поступі до тюремних перетворень.

\section{Список використаних джерел}

1. Полюмбецкий А. О происхождении и распространении пенитенциарной системы. Харьков : Университетская тип., 1854. 105 с.

2. Dixon W. H. John Howard, and the prison-world of Europe. 1850. New York : R. Carter \& Brothers, 428 p. URL: https://archive.org (дата звернення: 04.10.2018).

3. Hanway J. Solitude in Imprisonment: With Proper Profitable Labour and a Spare Diet, the Most Humane and Effectual Means of Bringing Malefactors, who Have Forfeited Their Lives, Or are Subject to Transportation, to a Right Sense of Their Condition; with Proposals for Salutary Prevention. London : Printed for J. Bew. 1776. 144 p.

4. Таганцев Н.С. Уголовное право (Общая часть). Часть 2. По изданию 1902 года. Allpravo.ru. 2003. URL: http://www.allpravo.ru/library/doc101p0/instrum 106/item1006.html (дата звернення: 04.11.2018).

5. Мор Т. Утопия. Золотая книга столь же полезная, как забавная, о наилучшем устройстве государства и о новом острове Утопия. Перевод и комментарии Малеина А. И. Предисловие Волгина В.П. Москва - Ленинград : Academia, 1935. 239 c. URL: http://goliard.ru (дата звернення: 11.10.2018).

6. Fox G. Fifty nine Particulars laid down for the Regulating things, and the taking away of Oppressing Laws, and Oppressors, and to ease the Oppressed. London. 1659. URL: https://universalistfriends.org/quf2002.html (дата звернення: 01.09.2018).

7. Eden W. Principles of Penal Law. London, 1771. 300 p. 
8. Hanway J. The Defects of Police, the Cause of Immorality, and the Continual Robberies committed, particularly in and about the Metropolis. London, 1775. 288 p.

9. Ignatieff $\mathrm{M}$. The Ideological Origins of the Penitentiary. Crime and Society: Readings in History and Theory / Fitzgerald M., McLennan G., Pawson J. Routledge, 1981. C. 31-49.

10. Мак-Говен Р. Добре організована в'язниця: Англія, 1780-1865 pp. Оксфордська історія в'язнищь: практика покарання в західному суспільстві / за ред. Норвала Морріса та Девіда Дж. Ротмена : пер. з англ. Київ : Всесвіт, 2009. С. 107-143.

11. McConville S. A History of English Prison Administration: 1750-1877. London : Routledge \& Kegan Paul, 1981. 534 p.

12. Melossi D., Pavarini M. The Prison and the Factory. Origins of the Penitentiary System (Critical criminology series) / Translated by G. Cousin. London : The Macmillan Press LTD, 1981. $244 \mathrm{p}$.

13. Webb S., Webb B. English prisons under local government. London : Longmans, Green. 1922. 261 p.

14. Слиозберг Г. Тюрьма в Англии (по книге Dr. Aschrott. P. S. Strafensystem and Gefängniswesen in England. Berlin 1887). Юридический вестник. Г. 20. 1888. Т. 27 [№ 1]. КН. 1 (январь). С. 103-131.

15. Андреященко Р. А. Пенитенциарная система Англии и Уэльса в XVI-XX вв. : Историко-юридическое исследование : автореф. дисс. ... канд. юрид. наук : 12.00.01. Екатеринбург, 2006. 26 с.

16. Васильева С. А. Идеология квакеров и возникновение филадельфийской системы тюремного содержания. Вестник Рязанского государственного университета имени С. А. Есенина. 2015. № 4 (49). С. 64-74.

17. Маруков А.Ф. Тюремная политика Англии и Уэльса: Историко-правовое исследование : дисс. ... д-ра юрид. наук 12.00.01. Москва : РГБ, 2003 (Из фондов Российской Государственной библиотеки). URL : http://dl1.lib.uaru.net/files/dfd/242/030522035.doc (дата звернення: 11.11.2018).

18. Тепляшин П. В. Европейские пенитенциарные системы (теоретикоприкладное и сравнительно-правовое исследование) : дисс. ... д-ра юрид. наук 12.00.08 / Сибирский юридический институт Министерства внутренних дел Российской федерации. Красноярск, 2018. 496 с.

19. Тепляшин П. В. Истоки и развитие английского тюрьмоведения: монография. Красноярск : Сибирский юридический институт МВД России, 2005. 253 с. URL: http://textarchive.ru/c-1673069-p5.html (дата звернення: 04.11.2018).

20. Гернет М. Н. От Томаса Мора до УК. Избранные произведения. Москва : Юридическая литература, 1974. С. 469-497.

21. Квакерская вера и практика. Книга христианской дисциплины Годового Собрания Друзей (квакеров) в Британи. П. 23.95. URL: http://quakers.ru (дата звернення: 04.09.2018).

22. Bernstein E. Cromwell and Communism: Socialism and Democracy in the Great English Revolution. Stuttgart. 1895. URL: https://www.marxists.org/reference/archive/ bernstein/works/1895/cromwell/17-bellers.htm (дата звернення: 04.09.2018).

23. Сокальська О. В. Вплив англійських протестантів на формування західних пенітенціарних систем. Пам'ятки права як відображення історичних процесів і рівня культури суспільства: до 500-річчя Реформації : матеріали XXXVII Міжнародної історико-правової конференції, 14-17 вересня 2017 р., с. Колочава / ред. колегія : I. Б. Усенко (голова), О.О. Малишев (відп.секр.), А. Ю. Іванова, В. Є. Кириченко, Н. М. Крестовська, І.В.Музика, Є. В. Ромінський, О.Н. Ярмиш. Київ-Херсон : ФОП Грінь Д. С., 2017. С. 93-99. 
24. James Oglethorpe (1696-1785). New Georgia Encyclopedia. URL: https://www.georgiaencyclopedia.org/articles/government-politics/james-oglethorpe1696-1785 (дата звернення: 14.11.2018).

25. Watt F. Emlyn, Sollom Dictionary of National Biography. 1885-1900. Volume 17. URL : https://en.wikisource.org/wiki/Emlyn,_Sollom_(DNB00); A complete collection of state-trials, and proceedings for high-treason, and other crimes and misdemeanors : from the reign of King Richard II to the end of the reign of King George I. Emlyn, Sollom 16971754., Salmon, Thomas 1679-1767. London : Printed for J. Walthoe sen. [etc.]. 1730. V 1-6. URL: https://catalog.hathitrust.org/Record/010460391 (дата звернення: 04.11.2018).

26. Vazquez I. R. Criminal Law Reform in the Eighteenth Century Europe. A Comparative Study: England, France, Spain. International Journal of Humanities and Social Science. Vol. 2 No. 4 [Special Issue - February 2012]. P. 26-37.

27. King's Bench Prison. Exploring Southwark and discovering its history. URL: http://www.exploringsouthwark.co.uk/kings-bench-prison/4593418850 (дата звернення: 14.10.2018).

28. Parliamentary Initiatives Motivated Howard's Prison Investigations. URL: http://www.acrosswalls.org/howard-prison-investigations/ звернення: 21.11.2018).

\section{o. Sokalska,}

PhD in Law, Associate Professor,

Senior Researcher of the Scientific-Research

Centre on Activities of the Bodies and

Establishments of the State Criminal-

Executive Service of Ukraine Probation of

Institute of Criminal-Executive Service

\section{ORIGINS OF ENGLISH PRISON REFORM (XVI-XVIII CENTURIES)}

The article examines the prison system of England in the XVI-XVIII centuries. The author analyzes the memory details of the penitentiary thought of England of that period, namely the views and ideas of the lawyers, public and religious doers on the state of prisons and the ways of reforming the prison system, which became the basis of the English penitentiary model. The latter was formed at the end of the XVIII century.

In particular, the following memory details of the penitentiary thought of England were introduced to the scientific circulation: «Essay Towards the Reformation of Newgate and Other Prisons in and about London» by T. Bray and «Solitude in Imprisonment: With Proper Profitable Labour and a Spare Diet, the Most Humane and Effectual Means of Bringing Malefactors...» by J. Henway.

It was cleared up that, for the first time, the idea of the educational influence, which is combined with the obligatory labour engagement for the purpose of the utilitarian use of the convicts without causing them unnecessary suffering during the imprisonment, was expressed in «Utopia» by T. More in 1516. In the middle of the XVII century the Quakerism's founder G. Fox formulated the demands to the 
prison staff and stressed on the harmfulness of the long-term imprisonment. In 1699 J. Bellers, for the first time, justified that the convicts' labour engagement and the crafts training for the purpose of their further employment should be the basis for the correctional punishment.

The first program of the real penitentiary transformation was introduced in 1702 in the essay of T. Brey about the prison reforms. He revealed systematically all the defects and gaps of the English prisons and proposed the ways of reforming them in the following directions: prison personnel, the regime and conditions of serving the sentences and the regular involvement of the prison priests into the spiritual care of inmates.

In the second half of the XVIII century, with the beginning of the punishment system transformation, the offenders correction became the main purpose of their imprisonment. The attention of the state officials and public figures was drawn to the prison reforms at that time. During 1775-1776 the ideas of the predecessors were generalized and deepened by J. Henway. In his works he introduced the main views on the principles of the organization of the correctional prisons, in particular the solitary confinement and proper living conditions, religious care and redemption, the obligatory labour engagement. J. Henway's ideas about the organization of the correctional prisons formed the basis of the English penitentiary model and the Philadelphia penitentiary system. They were used by the prison reformers, including J. Howard, at the first stage of the prison reform implementation at the end of the XVIII - early XIX century.

Keywords: England; prison system; prison reform; penitentiary ideas; Thomas Bray; Jonas Henway.

Надійшла до редакції 02.12.2018 